\begin{tabular}{|c|c|c|c|c|c|c|}
\hline \multirow{4}{*}{ [mpact Factor: } & ISRA (India) & 3.117 & SIS (USA) & $=0.912$ & ICV (Poland) & $=6.630$ \\
\hline & ISI (Dubai, UAE & $=0.829$ & РИНЦ (Russia) & $=0.156$ & PIF (India) & 1.940 \\
\hline & GIF (Australia) & $=0.564$ & ESJI (KZ) & $=5.015$ & IBI (India) & $=4.260$ \\
\hline & JIF & $=1.500$ & S.JF (Mor & $=5.667$ & OAJI (USA) & $=0.350$ \\
\hline
\end{tabular}

SOI: $\underline{1.1 / \mathrm{TAS}} \quad$ DOI: $\underline{10.15863 / \mathrm{TAS}}$
International Scientific Journal
Theoretical \& Applied Science
$\begin{array}{ll}\text { p-ISSN: } 2308-4944 \text { (print) } \quad \text { e-ISSN: } 2409-0085 \text { (online) } \\ \text { Year: } 2019 \quad \text { Issue: } 01 \quad \text { Volume: } 69 \\ \text { Published: } 23.01 .2019 \quad \underline{\text { http://T-Science.org }}\end{array}$

SECTION 32. Jurisprudence.
QR - Issue

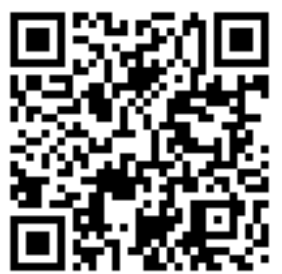

QR - Article

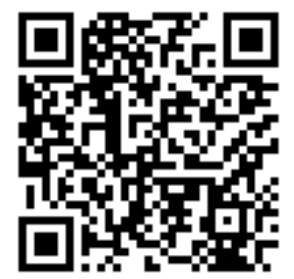

Anar Bahtiyarovich Gasimov graduate student of the National Academy of Sciences of Kyrgyz Republic

\title{
LEGAL BASIS OF DEVELOPMENT OF TAX CONTROL IN THE PERIOD OF INDEPENDENCE OF THE KYRGYZ REPUBLIC
}

\begin{abstract}
The author, in this study, having considered the basis of the administrative reforms of the Kyrgyz Republic during the period of independence, justified the reforms in the field of taxation that had begun. An administrative reform in the republic has undergone a radical reform of the control activities of the state, government bodies, including the control activities of tax authorities. Among the latter, an important role is played by the reform carried out at the end of 1991 and in subsequent years in Kyrgyzstan in the taxation system, the adoption of new laws regulating the procedure and conditions for paying taxes and the activities of the bodies controlling them. The author also in this study examines the development of the legal and organizational forms of tax control from 1991 to 1996.
\end{abstract}

Key words: people, reform, control, modernization, democracy, reorganization, politics, taxpayer, management, self-government.

Language: Russian

Citation: Gasimov, A. B. (2019). Legal basis of development of tax control in the period of independence of the Kyrgyz republic. ISJ Theoretical \& Applied Science, 01 (69), 206-209.

Soi: http://s-o-i.org/1.1/TAS-01-69-26 Doi: crossef https://dx.doi.org/10.15863/TAS.2019.01.69.26

\section{ПРАВОВЫЕ ОСНОВЫ РАЗВИТИЯ НАЛОГОВОГО КОНТРОЛЯ В ПЕРИОД НЕЗАВИСИМОСТИ КЫРГЫЗСКОЙ РЕСПУБЛИКИ}

\begin{abstract}
Аннотация: Автор, в данном исследовании, рассмотрев основы административных преобразований Кыргызской Республики в период независимости, обосновал начавшихся реформы в сфере налогообложения. Административным преобразованием в республике произошло кардинальное реформирование контрольной деятельности государства, органов государственной власти, в том числе и контрольной деятельности налоговых органов. Среди последних немаловажную роль имеет проведенная реформа в конце 1991 2. и в последующие годы в Кыргызстане в системе налогообложения, принятие новых законов, регламентирующих порядок и условия оплаты налогов, и деятельность контролирующих их органов. Также автор в настоящем исследовании рассматривает развития правовой и организационной формы налогового контроля с 19912 по 19962.

Ключевые слова: народ, реформа, контроль, модернизация, демократия, реорганизация, политика, налогоплательщик, управление, самоуправление.
\end{abstract}

\section{Introduction}

В рамках административных преобразований на государственном уровне осуществляется кардинальное реформирование контрольной деятельности государства и системы контрольных органов. Основными направлениями административных преобразований в данной области являются: 1) ограничение вмешательства государства в бизнес-процессы, 2) организационное разделение функций, касающихся экономической деятельности, надзора и контроля, оказания государственных услуг гражданам и юридическим лицам.

Исходя из этого, первоочередными задачами реформирования контрольной деятельности государства, в том числе и в налоговой сфере государственного управления являются: 1) уменьшение количества проверок и повышение их качества, 2) совершенствование статуса контрольно-надзорных органов. 


\begin{tabular}{|c|c|c|c|c|c|c|}
\hline \multirow{4}{*}{ Impact Factor: } & ISRA (India) & $=3.117$ & SIS (USA) & $=0.912$ & ICV (Poland) & $=6.630$ \\
\hline & ISI (Dubai, UAE & $=0.829$ & РИНЦ (Russia) & $=0.156$ & PIF (India) & $=1.940$ \\
\hline & GIF (Australia) & $=0.564$ & ESJI (KZ) & $=5.015$ & IBI (India) & $=4.260$ \\
\hline & JIF & $=1.500$ & SJIF (Morocco) & $=5.667$ & OAJI (USA) & $=0.350$ \\
\hline
\end{tabular}

Таким образом, административные преобразования в налоговой сфере государственного управления начелены, прежде всего, на реформирование организации налогового контроля.

\section{Materials and Methods}

По мнению автора исследования, осуществляемая в Кыргызской Республике административная реформа в налоговой сфере управления может быть предметом самостоятельного исследования и рассматриваться в исторической ретроспективе. Исторический подход к изучению того или иного социально-правового явления обеспечивает глубокое познание его сущности, a, следовательно, его объективной обусловленности и практической значимости [7]. Выявление эволюции сущности правового явления позволяет обнаружить тенденции развития его организационно-правовых форм в настоящем и будущем.

Исследование становления правовой и организационной форм налогового контроля Кыргызской Республики и одновременной их модернизации может осуществляться по самым различным основаниям. Думается, что в качестве такого основания должны быть взяты периоды развития налогового законодательства и о налоговой системе и органах финансового (в том числе налогового) контроля. Положив в основу периодизации именно эти критерии, административная реформа в налоговой сфере управления, по мнению автора, прошла в своем развитии два этапа.

Автор в настоящем исследовании рассматривает первого этапа развития правовой и организационной формы налогового контроля.

К данному этапу развития включается 19911996г.г. и его можно назвать подготовительным. В это время создаются специализированные органы налогового контроля, осуществляются первые мероприятия по их модернизации, проявляются существенные недостатки действующей системы организации налогового контроля.

В апреле 1990 г. были внесены изменения и дополнения в Конституцию Киргизской ССР, которые, по мнению С.Малабаева, были направлены на «осуществление первого этапа реформы политической системы. Они предусматривали развитие демократии, самоуправления народа, совершенствование избирательной системы, структуры и деятельности Советов» [1, с. 14].

В декабре 1990 г. на основе Закона «О реорганизации системы органов государственной власти и управления в Киргизской ССР и внесении изменений и дополнений в
Конституцию (Основной Закон) Киргизской ССР» были изменены структура исполнительного органа государственной власти [2]. Данное изменение произошло и в системе государственных органов осуществляющих налоговый контроль.

1990-году на основании вышеуказанных изменений была создана самостоятельное ведомство налоговая служба в составе министерства финансов.

Налоговая служба республики, как самостоятельное ведомство, была создана в 1990 году постановлением Правительства Кыргызской Республики, что стало отправной точкой отсчета в истории налоговой службы нашей страны. До этого ее функции выполняли финансовые органы, на которые в настоящее время возложены вопросы планирования и исполнения бюджета [8].

Кадровый состав Налоговой службы и еe структурных подразделений был сформирован из опытных финансистов, имеющих богатую практику контрольной деятельности. Они внесли весомый вклад в формирование и развитие налоговой службы.

С конца 1991 г., в независимом Кыргызстане складывалась весьма неблагоприятная экономическая ситуация: разрыв хозяйственных связей между предприятиями, полное отсутствие доходных источников бюджета, финансирование государственных расходов исключительно за счет эмиссии, развал товарного рынка и остановка производства.

Прежде всего, в условиях начавшихся рыночных отношений посредством налогов и других государственных платежей налоговая политика государства была направлена на развитие и регулирование предпринимательской и других видов экономической деятельности граждан, что было крайне тяжело [10].

Естественно, в сложившихся условиях налоговая политика Кыргызстана преследовала, прежде всего, фискальные интересы государства.

В это время естественному стремлению налогоплательщиков минимизировать свои обязательные налоговые платежи в бюджет и другие внебюджетные фонды, а в Кыргызстане в большей степени вообще уклониться от данных обязательных отчислений, государство предприняло попытку противопоставить собственные, по возможности, адекватные формы и методы правовой защиты. Среди последних немаловажную роль имеет проведенная реформа в конце 1991 г. и в последующие годы в Кыргызстане в системе налогообложения, принятие новых законов, регламентирующих порядок и условия оплаты налогов и деятельность контролирующих их органов. 


\begin{tabular}{|c|c|c|c|c|c|c|}
\hline \multirow{4}{*}{ Impact Factor: } & ISRA (India) & $=3.117$ & SIS (USA) & $=0.912$ & ICV (Poland) & $=6.630$ \\
\hline & ISI (Dubai, UAE & $=0.829$ & РИНЦ (Russia) & $=0.156$ & PIF (India) & $=1.940$ \\
\hline & GIF (Australia) & $=0.564$ & ESJI (KZ) & $=5.015$ & IBI (India) & $=4.260$ \\
\hline & JIF & $=1.500$ & SJIF (Morocco) & $=5.667$ & OAJI (USA) & $=0.350$ \\
\hline
\end{tabular}

Именно в тот период был принять Закон Кыргызской Республики от 6 марта 1992 года «О государственной налоговой службе».

Фактически это первый закон, определивший задачи и структуру Государственной налоговой службы в условиях начинавшихся тогда рыночных реформ, права и обязанности налоговых органов при осуществлении контроля за соблюдением налогового законодательства юридическими и физическими лицами. Здесь же предусматривается ответственность должностных лиц государственных налоговых инспекций за невыполнение или ненадлежащее выполнение своих обязанностей, несоблюдение установленной законодательством коммерческой тайны и т.д. Также освещены организация управления органами государственной налоговой службы, правовая и социальная защита работников государственной налоговой службы.

Также, в тот период для укрепления государственного контроля в сфере налогообложения вышел Указ Президента Кыргызской Республики от 19 февраля 1993 года №УП-60 «О создании специальных подразделений налоговых расследований при Государственной налоговой инспекции Республики Кыргызстан» [3]

Специальное подразделение налоговых расследований было создано в целях повышения эффективности деятельности Государственной налоговой инспекции Кыргызской Республики, а также предупреждения, выявления и пресечения нарушений налогового законодательства в республике.

В соответствии с Указом спецподразделение было укомплектовано сотрудниками Министерства внутренних дел, Государственного комитета по национальной безопасности, за которыми сохранялась правовая, социальная защита и льготы по прежнему месту работы. Министерством обороны были переданы спецподразделениям налоговых расследований легкое стрелковое оружие, боеприпасы и бронежилеты, а главами государственных администраций - помещения.

Численность вновь созданных специальных подразделений налоговых расследований составляла 150 человек [4]. Также по данному Указу для обеспечения поступления в бюджет налогов и других платежей в регионах республики в Управлениях Государственной налоговой инспекции Чуйской, Ошской, Талаской, Джалал-Абадской, Нарынской и Иссык-Кульской областей были созданы специальные подразделения налоговых расследований. В состав, которых входило по 17 человек откомандированных из органов внутренних дел Кыргызской Республики.
Указом Президента Кыргызской Республики от 10 февраля 1994 года «О чрезвычайных мерах по укреплению государственной и финансовой дисциплины» на базе спецподразделений был создан Департамент налоговой полиции при Министерстве финансов Кыргызской Республики. Данный нормативно-правовой акт сыграл важную роль в становлении нового контролирующего органа в сфере налогообложения Кыргызской Республики. Также были созданы Управления налоговой полиции по областям Департамента налоговой полиции при Правительстве Кыргызской Республики.

Необходимо отметить, что правовые и организационные основы деятельности вновь созданного органа устанавливались Постановлением Правительства Кыргызской Республики от 24 февраля 1994 года №84 «О дальнейшем углублении экономических реформ и мерах по реализации Указа Президента Кыргызской Республики от 10 февраля 1994 года «О чрезвычайных мерах по укреплению государственной и финансовой дисциплины». Как отмечал, Президент Кыргызской Республики в своем выступлении на республиканском совещании по усилению борьбы с преступностью и укреплению общественного порядка, «налоговая полиция находится в сложном положении в наведении порядка в сфере налогообложения»[5].

Указом Президента Кыргызской Республики от 26 июня 1995 года "О внесении изменений в Указ Президента Кыргызской Республики от 10 февраля 1994 года "О чрезвычайных мерах по укреплению государственной и финансовой дисциплины» [5] и Постановлением Правительства Кыргызской Республики от 3 июля 1995 года №258 "О вопросах налоговой полиции» Департамент налоговой полиции был преобразован в Управление налоговой полиции в составе Государственной налоговой инспекции при Министерстве финансов Кыргызской Республики, со штатной численностью 200 человек [6]

Также в этот период необходимо было разработать нормативной базы налогообложения Кыргызской Республики.

$$
\text { В результате проводимых }
$$
административных реформ в 1991-1994гг., был принят целый ряд законов в области налогообложения, вступивших в действие: Законы Кыргызской Республики «О Государственной налоговой инспекции при Министерстве финансов Кыргызской Республики» от 06 03.1992г., «Об основах налоговой системы КР от 14.04.1994г., «О налогах с предприятий, организаций и учреждений» от 13.01.1994г., «О налогах с 


\begin{tabular}{|c|c|c|c|c|c|c|}
\hline \multirow{4}{*}{ Impact Factor: } & ISRA (India) & $=3.117$ & SIS (USA) & $=0.912$ & ICV (Poland) & $=6.630$ \\
\hline & ISI (Dubai, UAE & $=0.829$ & РИНЦ (Russia) & $=0.156$ & PIF (India) & $=1.940$ \\
\hline & GIF (Australia) & $=0.564$ & ESJI (KZ) & $=\mathbf{5 . 0 1 5}$ & IBI (India) & $=4.260$ \\
\hline & JIF & $=1.500$ & SJIF (Morocco) & $=5.667$ & OAJI (USA) & $=0.350$ \\
\hline
\end{tabular}

населения» от 08.05.1993г., «О местных налогах и сборах» от 14.04.1994г., «О неналоговых платежах» от 14.04.1994г. и др.

\section{Conclusion}

За время, прошедшее после обретения независимости, в Кыргызстане осуществлены крупные меры по правовому обеспечению реформ в экономической и социальнополитической сфере.

Основными целями правовой реформы являются:

1. Создание действенных механизмов охраны и защиты прав и свобод человека;
2. Укрепление основ, гражданского общества и национальной государственности;

3. Правовое обеспечение социальноэкономических реформ;

4. Совершенствование контроля за исполнением законов [9].

Для обеспечения социально-экономической реформы Правительство Кыргызской Республики принимало многочисленных государственных программ. Среди них были программы направленные на совершенствование налоговой системы Кыргызской Республики.

\section{References:}

1. Soodanbekov, S. (2002). Problemyi stanovleniya $i$ razvitiya konstitutsionnopravovoy osnovyi gosudarstvennoy vlasti $v$ Kyirgyizskoy Respublike. (p.14). B.: Ilim.

2. (1996). Arhiv Prezidenta Kyirgyizskoy Respubliki. -F.1. -D.\#01-2. -T.10 ot 25.03.96.

3. (1993, February 19). O sozdanii spetsialnyih podrazdeleniy nalogovyih rassledovaniy pri Gosudarstvennoy nalogovoy inspektsii Respubliki Kyirgyizstan: Ukaz Prezidenta Respubliki Kyirgzyistan ot 19 fevralya 1993 goda. Slovo Kyirgyizstana, -\#38 (19290), 1.

4. Amanaliev, U. O. (2009). Primenenie organami finansovoy politsii KR upravlencheskih metodov dlya obespecheniya ekonomicheskoy bezopasnosti gosudarstva. Vestnik evraziyskoy akademii administrativnyih nauk, \#3 (8).Mosvka, 26.

5. (1994, February 11). O chrezvyichaynyih merah po ukrepleniyu gosudarstvennoy i finansovoy distsiplinyi: Ukaz Prezidenta
Respubliki Kyirgyizstan ot 10 fevralya 1994 goda. Slovo Kyirgyizstana, \#29 (19535), 2.

6. Amanaliev, U. O. (2010). Stanovlenie i razvitie organov finansovoy politsii KR. Monografiya. (p.14). Bishkek.

7. Gorelov, A. A. (2008). Formyi i metodyi, ispolzuemyie nalogovyimi organami pri osuschestvlenii meropriyatiy nalogovogo kontrolya. Administrativnoe $i$ munitsipalnoe parvo, \# 8.

8. Zrelov, A. P. (2005). Formyi nalogovogo kontrolya. Nalogi i nalogooblozhenie, \# 6.

9. Kobzar-Frolova, M. N. (2010). Rol i znachenie nalogovogo kontrolya i ucheta nalogoplatelschikov preduprezhdeniinalogovoy deliktnosti. Finansovoe parvo, \# 7.

10. Kucherov, I. I. (2006). O zakonodatelnom regulirovanii nalogovogo konsultirovaniya. Vash nalogovyiy advokat, \# 6. 